\title{
A RADIOCARBON CHRONOLOGY FOR PREHISTORIC AGRICULTURE IN THE SOCIETY ISLANDS, FRENCH POLYNESIA
}

\section{DANA LEPOFSKY}

\author{
Department of Archaeology, Simon Fraser University, Burnaby, British Columbia, Canada V5A 1S6
}

\begin{abstract}
I discuss a suite of 29 radiocarbon age determinations from four valleys on the islands of Mo'orea and Raiatea in the Society Archipelago. These dates provide the first sequence for the development of prehistoric agricultural production and human-induced environmental change in the Society Islands. Indirect evidence of small-scale agriculture, and by association, human occupation, dates to at least the 7th-10th centuries AD. Agricultural sites themselves date from the early 13th century $\mathrm{AD}$ until the late prehistoric/early historic period, with most agricultural activity clustering at the end of the temporal sequence. Valleys with the greatest arable potential were cultivated earlier than less preferred sites. Evidence for extensive landscape transformation in the Opunohu Valley, likely associated with clearing for agricultural purposes, begins soon after the earliest evidence for cultivation and continues throughout prehistory. A larger sample of ${ }^{14} \mathrm{C}$ determinations from stratigraphic excavations in both archaeological sites and "off-site" contexts is required to address many as yet unanswered questions about the prehistoric social and economic development of the Society Islands.
\end{abstract}

\section{INTRODUCTION}

The central role of agricultural production in maintaining complex Polynesian societies is well documented in the ethnographic and archaeological literature of several island groups (Kirch 1994; Kirch and Sahlins 1992; Sahlins 1958). Despite a long history of archaeological investigations in the Society Islands (Emory 1933; Emory and Sinoto 1964, 1965; Garanger 1964, 1980; Handy 1930), virtually no research has focused on prehistoric agricultural production. Previous studies concentrated on more spectacular sites, particularly marae (temple) sites (Eddowes 1991; Emory 1933, 1943; Emory and Sinoto 1965; Garanger 1964, 1980; Gerard 1974; Green 1967; Green and Green 1968; Verin 1962; Wallin 1993). Few agricultural sites have even been recorded for the Society Archipelago (Green and Descantes 1989; Edwards n.d.; Sinoto and Komori 1988), and none have been investigated thoroughly. There are no ${ }^{14} \mathrm{C}$ determinations for these few sites, and their age has been based on an assumed temporal association with contiguous non-agricultural sites.

Although $45{ }^{14} \mathrm{C}$ dates have been reported for the Society Islands (see Lepofsky 1994: Fig. 6.1), over half of these dates were made decades ago by the Gakushuin Laboratory before the advent of modern dating methods. These samples were taken on charcoal pretreated with acid but not with base (K. Kigoshi, personal communication, 1993), and none have stable isotope $\left(\delta^{13} \mathrm{C}\right)$ terminations. Researchers have recommended either that these dates be used with caution as general guides or discounted entirely (Anderson et al. 1994; Kirch 1986; Lepofsky 1994; Spriggs and Anderson 1993). Because several analyses of the Society Islands prehistory rely heavily on these earlier determinations (Descantes 1990; Eddowes 1991), it is critical these interpretations be tested with modern-day reliable ${ }^{14} \mathrm{C}$ measurements.

I discuss here a suite of $29{ }^{14} \mathrm{C}$ age determinations from the Society Archipelago collected as part of a larger research project on prehistoric agriculture and human-induced environmental change in the Society Islands (Lepofsky 1994). The two major goals of this larger study were to investigate the impact of prehistoric agricultural practices on the Society Island landscape, as well as a range of prehistoric agricultural sites in varied environmental settings. Seventeen of the ${ }^{14} \mathrm{C}$ age determinations originate from agricultural sites on the Islands of Mo'orea and Raiatea; 12 are from buried deposits in the lower and upper Opunohu Valley on Mo'orea.

These dates provide the first sequence for the development of prehistoric agricultural production and human-induced environmental change in the Society Islands. More than doubling the number of 
reliable dates available for all archaeological sites in the Society Islands, these dates greatly expand our knowledge of the chronology of human occupation in this island group as a whole.

\section{METHODS}

\section{The Archaeological Context}

My research focused on four valleys on the islands of Mo'orea and Raiatea chosen to represent a range of environmental variation. Work was conducted in the Opunohu and Niuroa Valleys on Mo'orea, and in the Fa'aroa and Matorea Valleys on the island of Raiatea (Fig. 1). In general, each of the valleys are defined by steep-sided mountains from which numerous small streams originate. The streams join into one or more central streams that run down the center of the valleys before discharging onto a fertile, alluvial plain at the valley mouth.

Beyond these basic similarities, the four valleys differ dramatically in their environmental settings, and thus in their potential agricultural productivity. Opunohu and $\mathrm{Fa}$ 'aroa, being among the largest and most fertile valleys, have the greatest potential for agricultural production. In contrast, the Niuroa and Matorea Valleys are more restricted spatially, and are less suited to agriculture (Lepofsky 1994).

\section{The Agricultural Sites}

I used a similar methodology to investigate the agricultural sites in each of the four valleys. With the exception of Fa'aroa Valley, where the agricultural sites had already been surveyed (Edwards n.d.), I conducted reconnaissance throughout the valleys to record and map agricultural sites and note their relationship to other non-agricultural archaeological remains. Whereas the lower alluvial plains were devoid of visible sites, the upper valleys were densely covered in archaeological remains. Surface sites in the upper valley were constructed of stone walls, alignments and platforms, as is typical of the archaeology of the Society Islands (Emory 1933). Agricultural sites, consisting of terraced complexes adjacent to large streams, and barrage complexes situated in low-energy streams, were a common component of the archaeological landscape in all valleys (Lepofsky 1994).

Several small test units were excavated in selected sites to expose the profiles needed to investigate the site's temporal development. Units were removed in arbitrary $10-$ to $15-\mathrm{cm}$ levels because of the difficulty of visually distinguishing subtle differences between deposits under the poor lighting conditions of the forest. Further, rodent disturbance, although localized, was frequently encountered and sometimes blurred depositional boundaries. Few artifacts were recovered. Charcoal specimens were collected both during excavation and from stratigraphic profiles after the excavation was completed. All charcoal specimens were placed in heavy polyethylene bags after collection.

The stratigraphy of the agricultural sites proved to be relatively straightforward (Lepofsky 1994). A charcoal-rich layer was found at the base of several units, and probably represents the remnants of initial burning of slope vegetation prior to construction of the terrace complex. Above this layer are usually 1 , and rarely, 2 or more layers of agricultural soils. These are generally characterized by an abundance of relatively fine sediments and charcoal flecking. I assume that the charcoal in the agricultural soils derives from the original vegetation clearing event and was incorporated into the deposits during terrace construction and/or use (c.f. Allen 1992). Thus, the charcoal in the agricultural deposits and in the charcoal layers below the agricultural soils date to a time immediately preceding terraced agriculture in that location. In the few sites with multiple agricultural layers, the charcoal found in the upper layers likely originated from the burning of successional vegetation growing between planting events. 


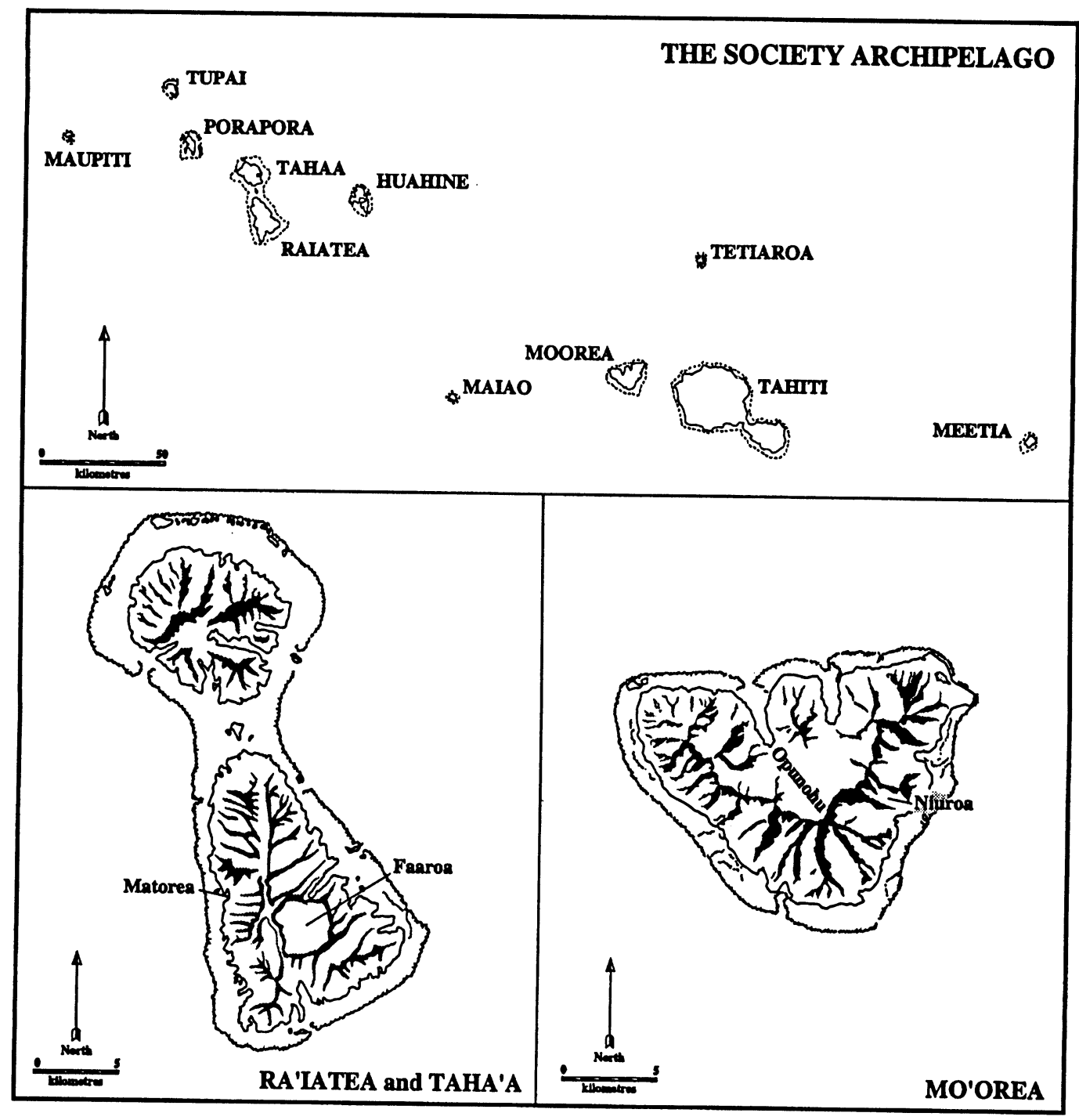

Fig. 1. Map showing the location of the study area. Top is the Society Archipelago, showing locations of the islands of Mo'orea and Raiatea. Bottom shows the locations of the four study sites (after Oliver 1974).

\section{The Opunohu Valley Buried Deposits}

To study human-induced change to the environment, I also examined "off-site" stratigraphic profiles in the Opunohu valley in areas with no visible archaeological remains. I examined 21 backhoe trenches (ranging in depth from 1-4 m) in the lower Opunohu valley, and 7 stream profiles in both the lower and upper valley. Charcoal particles, and anaerobically preserved plant remains in the water-logged sediments, were collected from discrete depositional layers for dating and taxonomic identification. As above, all samples were placed in heavy polyethylene bags.

The stratigraphy in the lower and upper valley has been described in detail elsewhere (Lepofsky 1994; Lepofsky, Kirch and Lertzman 1996). I summarize the stratigraphy here to place the ${ }^{14} \mathrm{C}$ deter- 
minations in context. In general, the stratigraphy of the lower Opunohu Valley consists of four main facies groups: 1) basal deposits; 2) reduced anaerobic deposits which are within and below the water table; 3) alluvial and colluvial facies; and 4) recent organically rich loams of alluvial origin.

Basal deposits or reduced, anaerobic deposits were the lowermost layer in the units. Basal deposits, reached in only five of the excavation units, are composed either of old colluvium originating from nearby slopes, or a hard, compact clay. The reduced, anaerobic deposits generally consist of extremely fine sediments, likely deposited at a time when the valley floor was marshy, and its hydrologic regime probably tidally controlled. Most of the reduced layers contain anaerobically preserved coconut roots and limbs or roots of various tree species. One unit contained species of seed endocarps and several early cultivated forms of coconuts (Cocos nucifera L.) preserved in their entirety except for the endosperm (Lepofsky, Harries and Kellum 1992).

Alluvial and/or colluvial deposits overlie the reduced, anaerobic layers. The colluvial deposits derived from mass wasting events on the surrounding slopes, and were spread onto the valley floor in major flood events. A hearth feature, containing charcoal and fire-altered rocks overlays the colluvial layer of one unit.

The alluvial layers represent more localized fluvial events than the colluvial deposits. Charcoal fragments were found within some of alluvial layers, especially in the profiles along the northwest valley floor. I assume that these charcoal fragments originate from vegetation burning for agricultural purposes. The species identification of the charcoal, and the fact that the charcoal is in a low-energy depositional environment, suggests that the charcoal was deposited close to the original location of vegetal burning.

The deposition of these colluvial and alluvial sediments onto the swampy terrain eventually transformed the valley floor into a drier alluvial flat. The increased sediment load in the valley floor originates from some kind of environmental disturbance upslope. The removal of ground-holding tree roots and other vegetation would account for the exposure and subsequent erosion of the sediments in the upper valley. As I propose elsewhere (Lepofsky 1994; Lepofsky, Kirch and Lertzman 1996), agriculture was likely the reason for clearing the upper valley vegetation. On the valley floor, the first evidence of human use of the newly created drier alluvial flat is the hearth feature and the charcoal fragments within the alluvial deposits.

The upper $0.5-1.5 \mathrm{~m}$ of each valley floor profile consists of organically rich loam deposits, some of which contain charcoal flecking. The upper deposits suggest a recent continuation of the colluvialalluvial depositional sequence described above. The relative abundance of charcoal in some of these deposits suggests the lower valley was cultivated. The stratigraphy of the upper valley stream profiles is similar to that described for the lower valley but with a greater influence of low-energy fluvial depositional processes. Charcoal-bearing clay layers occur throughout these stream profiles. The charcoal is assumed to originate from vegetation clearing, likely for agricultural purposes. As in the lower valley trenches, the species of charcoal, and its location in a low-energy depositional environment, suggest that it was deposited close to the original burning site.

\section{THE SOCIETY ISLANDS RADIOCARBON SEQUENCE}

I chose $29{ }^{14} \mathrm{C}$ samples from the numerous charcoal specimens and anaerobically preserved plant remains collected during the excavation of the agricultural sites in the four valleys and the Opunohu "off-site" trenches. All samples were selected to represent the greatest temporal variation and diversity of site types. Priority was given to samples collected from the walls of excavation units after profiles were drawn and strata had been designated. 
Seventeen of the ${ }^{14} \mathrm{C}$ age determinations derive from charcoal from the agricultural sites; 11 come from the Opunohu Valley agricultural sites; 2 originate from sites in each of the other 3 valleys. Most of the samples were from Opunohu because that valley was the focus of my larger research project (Lepofsky 1994), and the location of previous archaeological investigations (Green et al. 1967; Green and Descantes 1989). Numerous ${ }^{14} \mathrm{C}$ dates (several from the Gakushuin Laboratory) resulted from these earlier archaeological investigations. Sampling of dates from the other valleys was limited, but given financial constraints I chose to sample a single valley (i.e., Opunohu) intensively. The range of ${ }^{14} \mathrm{C}$ age determinations produced from the Opunohu contexts validates this approach. The remaining 12 samples come from charcoal and anaerobically preserved plant remains from the buried "off-site" Opunohu deposits. Eight of the samples came from the lower valley trenches; the final 4 samples are from stream profiles in the upper valley.

Most of the charcoal and anaerobically preserved plant remains from both the agricultural sites and the Opunohu stratigraphic profiles were measured using accelerator mass spectrometry at the Center for Accelerator Mass Spectrometry (CAMS) at the Lawrence Livermore National Laboratory, University of California. Two samples of anaerobically preserved coconuts from the valley floor trenches were dated using the conventional ${ }^{14} \mathrm{C}$ method by Beta Analytic, Inc. (Beta). All samples were pretreated for carbonates and humic acids using standard procedures, and the $\delta^{13} \mathrm{C} /{ }^{12} \mathrm{C}$ ratios were measured for all samples to establish ${ }^{13} \mathrm{C}$ adjusted, "conventional ${ }^{14} \mathrm{C}$ ages" following Stuiver and Polach (1977). Calibration of all ${ }^{14} \mathrm{C}$ ages and probability estimates were made using OXCAL v2.15 (Stuiver and Kra 1986). Forty years were subtracted for the Southern Hemisphere.

\section{The Agricultural Sites}

Figure 2 shows the ${ }^{14} \mathrm{C}$ determinations from the agricultural sites in the four valleys. Agricultural sites in this study date throughout prehistory, beginning in the early 13th century $\mathrm{AD}$ and continuing until the late prehistoric/early historic period. (Multiple intercepts in this portion of the radiocarbon curve do not allow us to distinguish between pre- and post-European contact ages.) Most of the agricultural sites date to the end of the sequence. Based on the sample of ages here, the valleys with the greatest arable potential-Opunohu and $\mathrm{Fa}^{\prime}$ aroa-were used earliest for agricultural production, while the less preferred sites were used later. The distribution of ages suggests an increasing number of agricultural sites were used through prehistory. Based on ${ }^{14} \mathrm{C}$ ages of non-agricultural sites from the Archipelago as a whole (Lepofsky 1994: Fig. 6.1), the growth of agricultural sites corresponds with population growth.

Unfortunately, the ${ }^{14} \mathrm{C}$ determinations do not inform upon length of use of individual agricultural sites. Based on the presence of only a single stratum in most of the agricultural sites, I conclude that most sites were used for only a single-use event. If I am correct that the charcoal originates from the initial clearing event, the ${ }^{14} \mathrm{C}$ dates correspond to the beginning of each use-event. However, what we cannot determine is how long after the initial clearing the site continued to be cultivated. In many cropping systems, gardens are left fallow for various lengths of time in order to replenish the soil. Subsequent use of these plots requires burning of successional vegetation. This would show up archaeologically as multiple stratigraphic layers, each containing charcoal (e.g., OPU-267). However, gardens can also be continuously cultivated with the addition of organic fertilizers to prevent soil depletion (Lepofsky 1994: Chapter 2). Thus, we have no way of distinguishing a garden plot which was cultivated for a short period of time and then abandoned, from those used for a considerably longer period. Distinguishing between these two scenarios has important implications for our understanding of the development of agricultural production in the Society Islands (Lepofsky 1994). 
M. Stuver and R.S. Kra ods. 1988 Radkarbon 28(28): 806-1030; OxCal V2.16 cub r.4 ed:12 prob/chron]

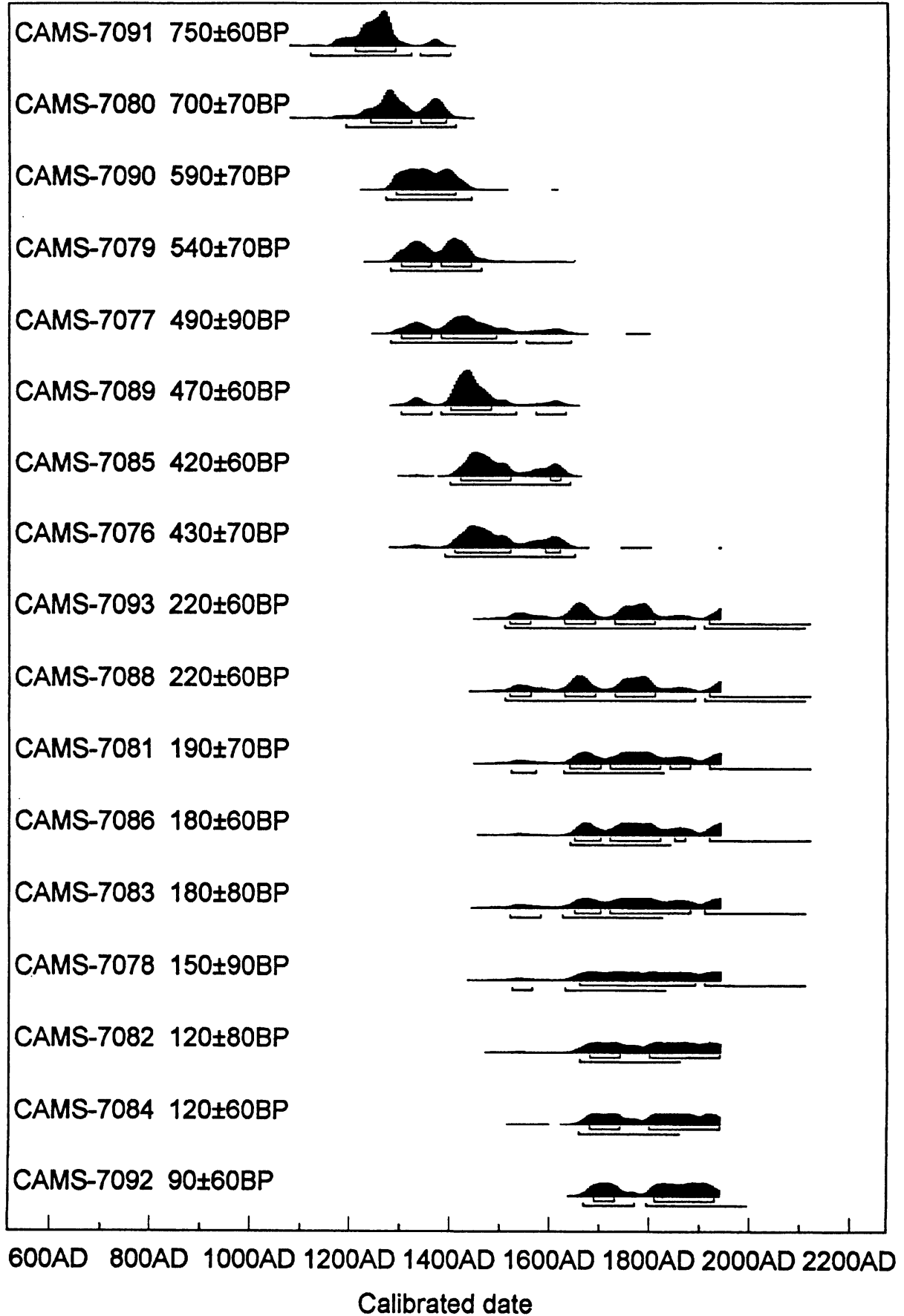

Fig. 2. Calibrated ${ }^{14} \mathrm{C}$ age determinations from agricultural sites in the Society Islands. Forty years have been subtracted for the Southern Hemisphere. 


\section{The Opunohu Valley Buried Deposits}

Figure 3 shows the ${ }^{14} \mathrm{C}$ determinations from the Opunohu "off-site" deposits. With the exception of three anomalous ${ }^{14} \mathrm{C}$ ages, the determinations from the off-site samples follow an age-depth progression. Two of the anomalous samples (CAMS-6253 and -6254) are from deeply buried, anaerobically preserved roots collected to date the deposition of the surrounding matrix. The samples derive from more recent trees whose roots extended into the older deposits. The other anomalous sample (CAMS-6250) comes from charcoal collected $40 \mathrm{~cm}$ below the surface of the valley floor. The modern age determination suggests that at least part of the upper surface of the valley floor relates to modern activity. That the deposition of the valley floor surface is so recent in part accounts for the absence of surface remains in this part of the Opunohu Valley.

The remaining nine age determinations represent a long sequence of agricultural activity in the Opunohu Valley, the earliest evidence of which comes from the anaerobically preserved coconuts deposited between the 7th-10th centuries $\mathrm{AD}$. The nature of the sediments indicate marshy conditions at the time of deposition. No determinations from the upper valley date the transformation of the valley floor from marsh to a drier alluvial flat. However, the process began some time after the deposition of the coconuts in the lower valley. Thus, large-scale clearance of the upper slopes, likely for agricultural purposes, probably began some time after the 7th century AD.

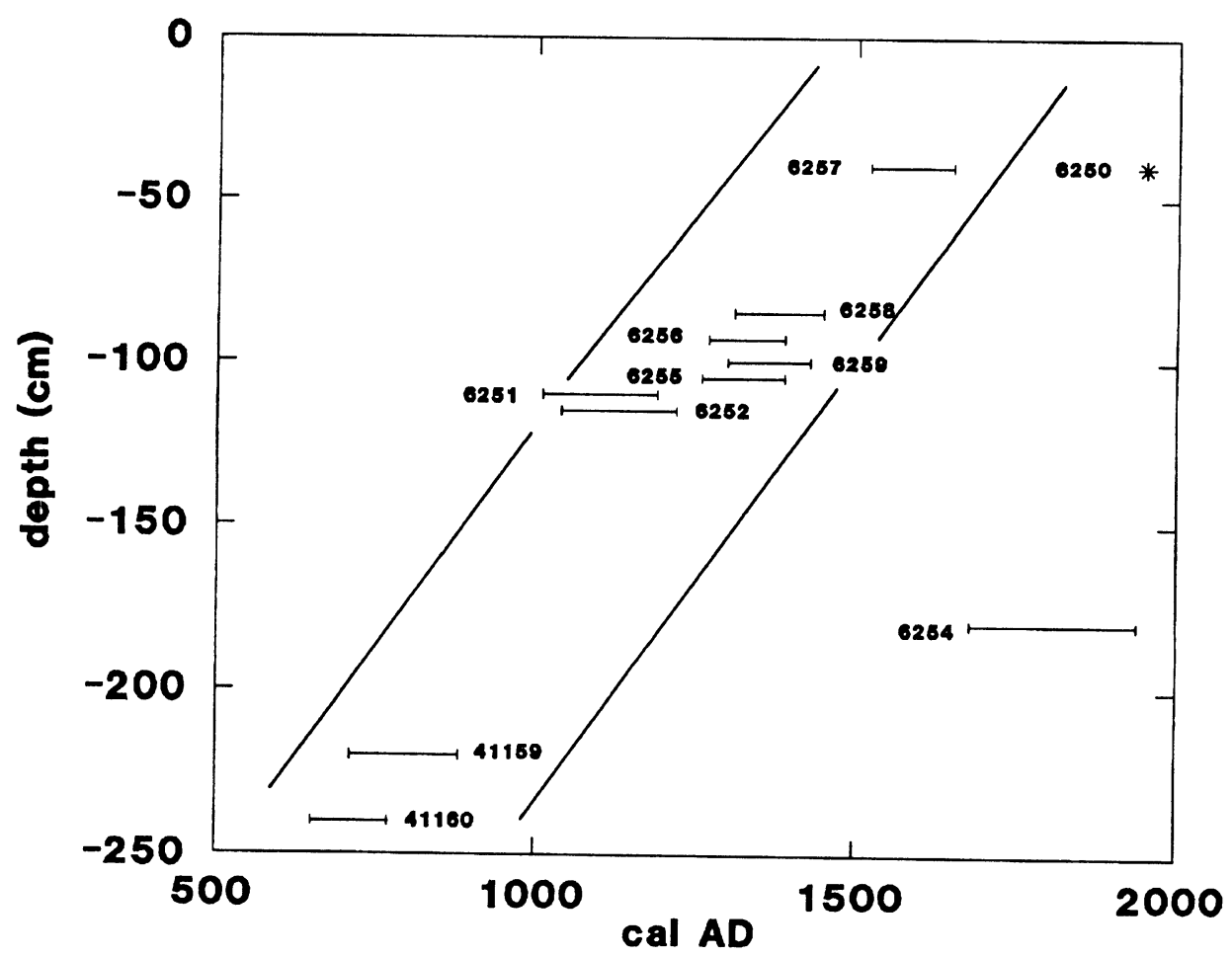

Fig. 3. Calibrated ${ }^{14} \mathrm{C}$ age determinations from Opunohu Valley "off-site" trenches. The ages are plotted as minimum and maximum ranges at $1 \sigma$, and are arranged by depth below surface. CAMS- 6253 is not represented in the figure; it dates a recent coconut root recovered at a depth of $3.2 \mathrm{~m}$ (see text). 
The ages of the hearth feature in the lower valley and the charcoal from the alluvial deposits in both the upper and lower valleys indicate widespread human use of the valley from the 11th-13th centuries $\mathrm{AD}$. With the exception of the hearth feature, the other ages likely date agricultural activity. The final date (CAMS-6257) suggests that in the upper valley vegetal burning associated with agriculture continued through the late prehistoric period in the upper valley. This is also supported by several age determinations from agricultural sites in the upper Opunohu Valley. No ${ }^{14} \mathrm{C}$ results date agricultural activities in the lower valley past the late 14th century, but, based on the increase in number of non-agricultural sites in Opunohu dating beyond this period (Green et al. 1967; Lepofsky 1994: Fig. 6.1), one can assume that agricultural production on the rich alluvial flat only became more important with time.

\section{Discussion}

The suite of ${ }^{14} \mathrm{C}$ ages presented here has larger implications for human settlement of the Society Islands. The age of the coconuts from the Opunohu Valley floor are among the earliest dates associated with human occupation in the Archipelago (Spriggs and Anderson 1993; Lepofsky et al. 1992). Significantly, these samples were found at the top of the marshy layer. The bottom of these layers was not reached in any excavation unit due to the high water table. However, the deposit continued at least another $60 \mathrm{~cm}$, suggesting that human colonization of the Opunohu Valley, and the entire Archipelago, predates, by an undetermined period of time, the 7th century ages associated with the coconuts and the top of the marshy layer.

The age sequence from the Opunohu Valley "off-site" trenches date a sequence of considerable human modifications to the environment. Sometime after the 7th century extensive disturbance upslope led to the massive deposition of sediments onto the lower valley. The evidence for burning upslope suggests that the clearing of vegetation for agricultural purposes may have been the cause of this disturbance. The ${ }^{14} \mathrm{C}$ ages from both the agricultural sites and "off-site" contexts suggest that agriculture was well established throughout the valley by the 12 th century $\mathrm{AD}$. The modern ${ }^{14} \mathrm{C}$ age from the charcoal from $40 \mathrm{~cm}$ below the current ground surface in the lower valley indicates that the process of erosion and deposition associated with agricultural practices continues in the Opunohu Valley today.

The ages from the agricultural sites demonstrate that human populations were well established in the inland valleys of the Society Islands relatively early in prehistory. This is demonstrated by the 13th century AD ages from Fa'aroa Valley and site OPU-159 in Opunohu Valley. Although extensive inland settlements are well documented on Tahiti (Garanger 1964, 1980; Malardé 1936; Verin 1962) and Mo'orea (Green et al. 1967; Green and Descantes 1989), only the Opunohu sites have been dated. The earliest ${ }^{14} \mathrm{C}$ age from Green's work in Opunohu comes from site OPU-4, a sub surface round-ended house dating to $\mathrm{AD} 1281-1404$ (AMNH-204; ${ }^{1} 10$ not corrected for $\delta^{13} \mathrm{C}$; Stuiver and Becker 1993). However, this site is ca. $0.75 \mathrm{~km}$ inland from Opunohu Bay, whereas the dated agricultural sites from Opunohu and Fa'aroa are $c a .2 .5 \mathrm{~km}$ inland. All other dated sites from Green's work in Opunohu date occur later in prehistory, and the results are of questionable reliability from Gakushuin. Thus, the early ages on the agricultural sites firmly establish the relative antiquity of inland settlement in the Opunohu Valley and elsewhere in the Society Archipelago.

The ${ }^{14} \mathrm{C}$ determinations from this study have important implications for the way archaeologists interpret the archaeological record of the Society Islands. The ${ }^{14} \mathrm{C}$ samples from the agricultural

${ }^{1} \mathrm{AMNH}=$ American Museum of Natural History, "Isotopes, Inc., Radiocarbon Code Number I (AMNH-204)" 
sites were collected from sites, which, based on surface remains, were assumed to be part of a single larger settlement complex. However, the widely varied ${ }^{14} \mathrm{C}$ ages indicate that this assumption is not valid. This is particularly evident in Opunohu, from which the largest sample of dates derive, but it also seems to be the case in the Fa'aroa and Matorea Valleys. In Opunohu, the wide range of ages calls for a rethinking of previous interpretations of the settlement history of that valley (e.g., Green et al. 1967; Descantes 1990), and provides a cautionary note for the interpretation of the archaeological landscape elsewhere in the Archipelago.

The ${ }^{14} \mathrm{C}$ ages associated with human-induced changes to the landscape further indicate the need for caution when interpreting the surface archaeological record. As a result of massive erosion and deposition, archaeological sites visible on the surface will necessarily date to the period after these major disturbances. The evidence from the Opunohu Valley presented here, and pollen evidence from elsewhere on Mo'orea and Tahiti (Parkes and Flenley 1990) suggest that landscape disturbance began as early as the 7th century $\mathrm{AD}$. Thus, we can expect surface sites to date to after the 7th century-an expectation borne out by the extant dated archaeological remains in the island group (Lepofsky 1994: Fig. 6.1). If archaeologists are interested in the earlier part of settlement history in the Society Islands, they must be prepared to look considerably deeper than the surface archaeological record.

The chronometric evidence presented here documents a 1000-yr sequence of human occupation of the Society Islands, beginning with small-scale agriculture in the valleys, followed by widespread clearing for agriculture and significant human-induced changes to the landscape, and finally extensive human settlement extending to the inland valleys. Although the results presented here go a long way towards increasing our knowledge of the settlement history of the Society Islands, they also demonstrate how little we know about the prehistory of that island group. To understand more fully the history of human occupation in the Society Islands Archipelago, we require a larger sample of ${ }^{14} \mathrm{C}$ determinations from stratigraphic excavations in both archaeological sites and "off-site" contexts.

\section{ACKNOWLEDGMENTS}

I am grateful to the Center for Accelerator Mass Spectrometry at Lawrence Livermore National Laboratory, in particular Jay Davis, for a generous grant for many of my accelerator dates. Erle Nelson of Simon Fraser University and also an affiliate of the Center, offered much assistance with the preparation and interpretation of the ${ }^{14} \mathrm{C}$ specimens and with the preparation of this manuscript. Patrick Kirch made helpful comments on an earlier draft of this manuscript. Support for field research and part of the ${ }^{14} \mathrm{C}$ determinations was provided by a National Science Foundation Dissertation Improvement Grant (BNS-9106761), the National Geographic Society Committee for Research and Exploration (4586-91) and a Wenner Gren Foundation Predoctoral Small Grant (Gr. 5415). This is Contribution No. 37 of the Gump Biological Research Station.

\section{ARCHAEOLOGICAL SAMPLES}

\section{The Opunohu Valley Agricultural Sites (OPU-) Series}

\section{CAMS-7076. Opunohu Valley}

$470 \pm 70 \mathrm{BP}$

$\delta^{13} C=-25.0 \%$

Charcoal from site OPU-267, a small terraced agricultural complex in the upper Opunohu Valley, Tupaururu. From Terrace W, EU 9, Layer 2, a possible agricultural layer, east wall, $10 \mathrm{~cm}$ below surface. $1410 \mathrm{cal} \mathrm{AD}(0.87) 1520 \mathrm{cal} \mathrm{AD}, 1590 \mathrm{cal} \mathrm{AD}(0.13) 1620 \mathrm{cal} \mathrm{AD}$ at 1 o. 
CAMS-7077. Opunohu Valley

$530 \pm 90 \mathrm{BP}$

$\delta^{13} C=-25.0 \%$

Charcoal from Site OPU-267, a small terraced agricultural complex in upper Opunohu Valley, Tupaururu. From EU 9, Layer 5, a possible agricultural layer, east wall, $39 \mathrm{~cm}$ below surface. 1300 cal AD (0.27) $1360 \mathrm{cal} \mathrm{AD,} 1380 \mathrm{cal} \mathrm{AD} \mathrm{(0.73)1490} \mathrm{cal} \mathrm{AD} \mathrm{at} 1 \sigma$.

\section{CAMS-7078. Opunohu Valley}

$190 \pm 90 \mathrm{BP}$

$\delta^{13} C=-25.7 \%$

Composite charcoal sample from Site OPU-27, a terraced agricultural complex in upper Opunohu Valley, Amehiti. From EU 16, Layer 2, a possible agricultural layer, 2-22 cm below surface. 1660 cal AD (0.87) $1890 \mathrm{cal} \mathrm{AD,} 1910 \mathrm{cal} \mathrm{AD} \mathrm{(0.13)} 1950 \mathrm{cal} \mathrm{AD}$ at $1 \sigma$.

CAMS-7079. Opunohu Valley

$580 \pm 70$ BP

$\delta^{13} C=-28.9 \%$

Composite charcoal sample from Site OPU-159, a terraced agricultural complex directly associated with marae (temple) in upper Opunohu Valley, Tupaururu. From Terrace 22, EU 1, Layer 3, cultural fill deposited during terrace construction, $20-62 \mathrm{~cm}$ below surface. Large retouched flake, triangular adze butt and quadrangular adze were found at the base of the layer. $1300 \mathrm{cal} \mathrm{AD}(0.45) 1360 \mathrm{cal} \mathrm{AD}$, $1380 \mathrm{cal} \mathrm{AD}(0.55) 1440 \mathrm{cal} \mathrm{AD}$ at $1 \sigma$.

CAMS-7080. Opunohu Valley

$740 \pm 70 \mathrm{BP}$

$\delta^{13} \mathrm{C}=-28.4 \%$

Charcoal from Site OPU-159, a terraced agricultural complex directly associated with marae (temple) in upper Opunohu Valley, Tupaururu. From Terrace 13, EU 2, Layer 2, a probable agricultural layer, $13 \mathrm{~cm}$ below surface, west wall. Unretouched flake was found at the base of the layer. 1240 $\mathrm{cal} \mathrm{AD}(0.66) 1320 \mathrm{cal} \mathrm{AD}, 1340 \mathrm{cal} \mathrm{AD}(0.34) 1390 \mathrm{cal} \mathrm{AD}$ at $1 \sigma$.

CAMS-7081. Opunohu Valley

$230 \pm 70 \mathrm{BP}$

$\delta^{13} C=-23.2 \%$

Charcoal from Site OPU-283, an extensive barrage site complex in upper Opunohu Valley, Tupaururu. From Terrace 12, EU 1, Layer 3, water logged agricultural layer, $20 \mathrm{~cm}$ below surface. 1640 $\mathrm{cal} \mathrm{AD} \mathrm{(0.26)1700} \mathrm{cal} \mathrm{AD,} 1720 \mathrm{cal} \mathrm{AD}(0.53) 1820 \mathrm{cal} \mathrm{AD}, 1840 \mathrm{cal} \mathrm{AD}(0.10) 1880 \mathrm{cal} \mathrm{AD}, 1920$ cal AD (0.12) $1950 \mathrm{cal} \mathrm{AD}$ at $1 \sigma$.

CAMS-7085. Opunohu Valley

$460 \pm 60 \mathrm{BP}$

$\delta^{13} C=-24.9 \%$

Charcoal from Site OPU-286, a small terraced agricultural site in upper Opunohu Valley, Tupaururu. From Terrace 1, EU 3, Layer 2, a probable agricultural layer, west wall, $19 \mathrm{~cm}$ below surface. 1420 cal AD (0.89) $1520 \mathrm{cal} \mathrm{AD,} 1600 \mathrm{cal} \mathrm{AD} \mathrm{(0.11)} 1620 \mathrm{cal} \mathrm{AD}$ at $1 \sigma$.

\section{CAMS-7086. Opunohu Valley}

$220 \pm 60 \mathrm{BP}$

$\delta^{13} C=-25.0 \%$

Charcoal from Site OPU-286, a small terraced agricultural site in upper Opunohu Valley, Tupaururu. From Terrace 1, EU 3, Layer 4, fill associated with terrace construction, west wall, $90 \mathrm{~cm}$ below surface. $1650 \mathrm{cal} \mathrm{AD}(0.24) 1700 \mathrm{cal} \mathrm{AD}, 1720 \mathrm{cal} \mathrm{AD}(0.56) 1820 \mathrm{cal} \mathrm{AD}, 1850 \mathrm{cal} \mathrm{AD}(0.07) 1870 \mathrm{cal}$ $\mathrm{AD}, 1920 \mathrm{cal} \mathrm{AD}(0.13) 1950 \mathrm{cal} \mathrm{AD}$ at $1 \sigma$.

CAMS-7082. Opunohu Valley

$160 \pm 80 \mathrm{BP}$

$\delta^{13} C=-24.7 \%$

Charcoal from Site OPU-285, an extensive multipurpose terraced site located on ridge of Mt. Rotui and flat at mouth of Opunohu Valley. From Terrace 63, EU 2, Layer 3, earth oven feature in terrace 
on upper ridge, $14-16 \mathrm{~cm}$ below surface, north wall. $1680 \mathrm{cal} \mathrm{AD} \mathrm{(0.33)} 1740 \mathrm{cal} \mathrm{AD}, 1800 \mathrm{cal} \mathrm{AD}$ (0.67) $1940 \mathrm{cal} \mathrm{AD}$ at $1 \sigma$.

CAMS-7083. Opunohu Valley

$220 \pm 80 \mathrm{BP}$

$\delta^{13} \mathrm{C}=-27.8 \%$

Charcoal from Site OPU-285, an extensive multi-purpose terraced site located on ridge of Mt. Rotui and flat at mouth of Opunohu Valley. From Terrace 77, EU 4, Layer 2, a possible agricultural layer in terrace on upper ridge, $10 \mathrm{~cm}$ below surface, west wall. $1650 \mathrm{cal} \mathrm{AD}(0.23) 1700 \mathrm{cal} \mathrm{AD}, 1720$ (0.65) $1880 \mathrm{cal} \mathrm{AD,} 1910 \mathrm{cal} \mathrm{AD} \mathrm{(0.12)} 1950 \mathrm{cal} \mathrm{AD}$ at $1 \sigma$.

\section{CAMS-7084. Opunohu Valley}

$160 \pm 60 \mathrm{BP}$

$\delta^{13} C=-24.4 \%$

Charcoal from Site OPU-285, an extensive multi-purpose terraced site located on ridge of Mt. Rotui and flat at mouth of Opunohu Valley. From EU 7. Layer 1, an occupation layer of house on lower flat. $1680 \mathrm{cal} \mathrm{AD}(0.34) 1740 \mathrm{cal} \mathrm{AD}, 1800(0.66) 1940 \mathrm{cal} \mathrm{AD}$ at $1 \sigma$.

THE NIUROA VALLEY AGRICULTURAL SITE (NIU-1) SERIES

CAMS-7092. Niuroa Valley

$130 \pm 60 \mathrm{BP}$

$\delta^{13} C=-24.2 \%$

Charcoal from Site NIU-1, a terraced agricultural complex in upper Niuroa Valley. From Terrace 15, EU 3, Layer 2, terrace fill, 14-36 cm below surface. $1690 \mathrm{cal} \mathrm{AD} \mathrm{(0.26)} 1730 \mathrm{cal} \mathrm{AD,} 1810(0.74)$ $1930 \mathrm{cal} \mathrm{AD}$ at $1 \sigma$.

\section{CAMS-7093. Niuroa Valley}

$$
\begin{array}{r}
260 \pm 60 \mathrm{BP} \\
\delta^{13} \mathrm{C}=-25.0 \% 0
\end{array}
$$

Charcoal from Site NIU-1, a terraced agricultural complex in upper Niuroa Valley. From Terrace 15, EU 3, Layer 4, charcoal concentration below possible agricultural soil, $55-64 \mathrm{~cm}$ below surface. Possibly represents the original vegetal burn to clear for terrace construction. $1520 \mathrm{cal} \mathrm{AD}(0.08)$ $1560 \mathrm{cal} \mathrm{AD}, 1630 \mathrm{cal} \mathrm{AD}(0.34) 1690 \mathrm{cal} \mathrm{AD}, 1730 \mathrm{cal} \mathrm{AD}(0.50) 1810 \mathrm{cal} \mathrm{AD}, 1920 \mathrm{cal} \mathrm{AD}(0.08)$ $1950 \mathrm{cal} \mathrm{AD}$ at $1 \sigma$.

\section{THE MATOREA VALLEY AGRICULTURAL SITE (MAT-1) SERIES}

\section{CAMS-7088. Matorea Valley}

$$
\begin{array}{r}
260 \pm 60 \mathrm{BP} \\
\delta^{13} C=-25.3 \% \circ
\end{array}
$$

Composite charcoal from Site MAT-1, an extensive terraced agricultural site complex in upper Matorea Valley. From Terrace 57, EU 4, Layer 2, an agricultural layer, $15-50 \mathrm{~cm}$ below surface. $1520 \mathrm{cal} \mathrm{AD}(0.08) 1560 \mathrm{cal} \mathrm{AD}, 1630 \mathrm{cal} \mathrm{AD}(0.34) 1690 \mathrm{cal} \mathrm{AD}, 1730 \mathrm{cal} \mathrm{AD}(0.50) 1810 \mathrm{cal} \mathrm{AD}$, $1920 \mathrm{cal} \mathrm{AD}(0.08) 1950 \mathrm{cal} \mathrm{AD}$ at $1 \sigma$.

CAMS-7089. Matorea Valley

Composite charcoal sample from Site MAT-1, an extensive terraced agricultural site complex in upper Matorea Valley. From Terrace 21, EU 1, Layer 2, an agricultural layer, 22-30 cm below surface. $1400 \mathrm{cal} \mathrm{AD}(1.00) 1480 \mathrm{cal} \mathrm{AD}$ at $1 \sigma$. 
THE FA'AROA VALLEY AGRICULTURAL SITE (FAA-1) SERIES

CAMS-7090. Fa'aroa Valley

$630 \pm 70 \mathrm{BP}$

$\delta^{13} C=-25.6 \%$

Charcoal from Site FAA-1, part of extensive terraced agricultural complex, map zone A2 in upper Fa'aroa Valley. From Terrace 41, EU 5, Layer 5, terrace fill underlying agricultural layer, west wall, $26 \mathrm{~cm}$ below surface. $1290 \mathrm{cal} \mathrm{AD} \mathrm{(1.00)} 1410 \mathrm{cal} \mathrm{AD}$ at $1 \sigma$.

CAMS-7091. Fa'aroa Valley

$790 \pm 60 \mathrm{BP}$

$\delta^{13} C=-26.1 \%$

Charcoal from Site FAA-1, part of an extensive terraced agricultural complex, map zone A2 in upper Fa'aroa Valley. From Terrace 41, EU 5, Layer 5, terrace fill underneath agricultural layer, west wall, $43 \mathrm{~cm}$ below surface. $1210 \mathrm{cal} \mathrm{AD} \mathrm{(1.00)} 1290 \mathrm{cal} \mathrm{AD}$ at $1 \sigma$.

\section{THE OPUNOHU VALLEY “OFF-SITE" SERIES}

CAMS-6250. Opunohu Valley

$$
\begin{array}{r}
\text { >modern } \\
\delta^{13} C=-27.6 \%
\end{array}
$$

Charcoal from Opunohu valley floor. From Stream profile, EU 22, Layer 1, charcoal lens, northeast bank, $40 \mathrm{~cm}$ below surface.

CAMS-6251. Opunohu Valley

$970 \pm 90 \mathrm{BP}$

$\delta^{13} C=-22.8 \% 0$

Charcoal from Opunohu valley floor. From Stream profile, EU 22, Layer 3b, possible agricultural layer, northeast face, $1.1 \mathrm{~m}$ below surface. $1010 \mathrm{cal} \mathrm{AD}(1.00) 1190 \mathrm{cal} \mathrm{AD}$ at $1 \sigma$.

CAMS-6254. Opunohu Valley

$160 \pm 60 \mathrm{BP}$

$\delta^{13} C=-27.8 \%$

Anaerobically preserved uncharred wood from Opunohu valley floor. From Stream profile, EU 22, Layer 7, an waterlogged deposit, northeast bank, $1.8 \mathrm{~m}$ below surface. Collected below current water table. $1680 \mathrm{cal} \mathrm{AD} \mathrm{(0.34)1740} \mathrm{cal} \mathrm{AD,} 1800 \mathrm{cal} \mathrm{AD} \mathrm{(0.66)1940} \mathrm{cal} \mathrm{AD} \mathrm{at} 1 \sigma$.

CAMS-6252. Opunohu Valley

$920 \pm 60 \mathrm{BP}$
$\delta^{13} \mathrm{C}=-27.9 \%$

Charcoal from Opunohu valley floor. From EU 5, Layer 3, a probable hearth feature, southwest wall, $1.10 \mathrm{~m}$ below surface. $1040 \mathrm{cal} \mathrm{AD} \mathrm{(1.00)} 1220 \mathrm{cal} \mathrm{AD}$ at $1 \sigma$.

CAMS-6253. Opunohu Valley

$150 \pm 70 \mathrm{BP}$

$\delta^{13} C=-26.5 \%$

Anaerobically preserved coconut root from Opunohu valley floor. From EU 20, Layer 6b, northwest wall, $3.4 \mathrm{~m}$ below surface. $1680 \mathrm{cal} \mathrm{AD}(0.31) 1740 \mathrm{cal} \mathrm{AD}, 1800 \mathrm{cal} \mathrm{AD}(0.69) 1930 \mathrm{cal} \mathrm{AD}$ at $1 \sigma$.

CAMS-6255. Opunohu Valley

$720 \pm 60 \mathrm{BP}$

$\delta^{13} C=-26.4 \%$

Charcoal from Opunohu valley floor. From Stream profile, EU 23, Layer 2, a possible agricultural layer, east bank, $1.0 \mathrm{~m}$ below surface. $1260 \mathrm{cal} \mathrm{AD} \mathrm{(0.59)} 1320 \mathrm{cal} \mathrm{AD,} 1350 \mathrm{cal} \mathrm{AD} \mathrm{(0.41)} 1390 \mathrm{cal}$ $\mathrm{AD}$ at $1 \sigma$. 
BETA 41159. Opunohu Valley

$1270 \pm 60 \mathrm{BP}$

$\delta^{13} \mathrm{C}=-28.5 \%$

Coconut husk from anaerobically preserved coconut from Opunohu valley floor. From Stream profile, EU 23, Layer 7, a waterlogged deposit associated with whole coconuts and other anaerobically preserved plant remains, east bank, $2.2 \mathrm{~m}$ below surface. $710 \mathrm{cal} \mathrm{AD} \mathrm{(1.00)} 880 \mathrm{cal} \mathrm{AD}$ at $1 \sigma$.

BETA 41160. Opunohu Valley

$1360 \pm 60 \mathrm{BP}$

$\delta^{13} C=-25.4 \%$

Coconut husk from anaerobically preserved coconut from Opunohu valley floor. From Stream profile, EU 23, Layer $6 \mathrm{~b}$, a water logged deposit associated with whole coconuts and various other anaerobically preserved plant remains, east bank, $2.4 \mathrm{~m}$ below surface. $650 \mathrm{cal} \mathrm{AD}(1.00) 770 \mathrm{cal} \mathrm{AD}$ at $1 \sigma$.

CAMS-6256. Opunohu Valley

$710 \pm 60 \mathrm{BP}$

$\delta^{13} C=-25.3 \%$

Charcoal from Upper Opunohu valley, Tupaururu. From Stream profile, EU 25; Layer 3, a reduced clay layer, east bank, ca. $90 \mathrm{~cm}$ below surface. $1270 \mathrm{cal} \mathrm{AD} \mathrm{(0.55)} 1320 \mathrm{cal} \mathrm{AD,} 1350 \mathrm{cal} \mathrm{AD} \mathrm{(0.45)}$ $1390 \mathrm{cal} \mathrm{AD}$ at $1 \sigma$.

\section{CAMS-6259. Opunohu Valley}

$600 \pm 60 \mathrm{BP}$ $\delta^{13} \mathrm{C}=-30.2 \%$

Charcoal from Upper Opunohu valley, Tupaururu. From Stream profile, EU 25, Layer 3, a waterlogged deposit with anaerobically preserved plant remains, east bank, $c a .1 .0 \mathrm{~m}$ below surface. 1300 cal $\mathrm{AD}(0.55) 1360 \mathrm{cal} \mathrm{AD}, 1380 \mathrm{cal} \mathrm{AD}(0.45) 1430 \mathrm{cal} \mathrm{AD}$ at $1 \sigma$.

\section{CAMS-6257. Opunohu Valley}

$350 \pm 60 \mathrm{BP}$

$\delta^{13} \mathrm{C}=-26.4 \%$

Charcoal from Upper Opunohu valley, Tupaururu. From Stream profile, EU 26, Layer 2, a gleyed clay layer, east bank, $40 \mathrm{~cm}$ below surface. $1520 \mathrm{cal} \mathrm{AD} \mathrm{(1.00)} 1650 \mathrm{cal} \mathrm{AD}$ at $1 \sigma$.

CAMS-6258. Opunohu Valley

$560 \pm 60 \mathrm{BP}$

$\delta^{13} \mathrm{C}=-25.8 \%$

Charcoal from Upper Opunohu valley, Tupaururu. From Stream profile, EU 26, Layer 5, a gleyed clay layer, east bank, $85 \mathrm{~cm}$ below surface. $1310 \mathrm{cal} \mathrm{AD}(0.29) 1350 \mathrm{cal} \mathrm{AD}, 1390 \mathrm{cal} \mathrm{AD} \mathrm{(0.71)} 1450$ cal $\mathrm{AD}$ at $1 \sigma$.

\section{REFERENCES}

Allen, J. 1992 Farming in Hawai'i from colonization to contact: Radiocarbon chronology and implications for cultural change. New Zealand Journal of Archaeology 14: 45-66.

Anderson, A., Leach, H., Smith, I. and Walter, R. 1994 Reconsideration of the Marquesan sequence in East Polynesian prehistory, with particular reference to Hane (MUH1). Archaeology in Oceania. 29: 29-52.

Descantes, C. (ms.) 1990 Symbolic Stone Structures: Protohistoric and Early Historic Settlement Patterns of the 'Opunohu Valley, Mo'orea. M.A. thesis, University of Auckland: 203 p.

Eddowes, M. D. (ms.) 1991 Ethnohistorical Perspectives on the Marae of the Society Islands: The Sociology of Use. M.A. thesis, University of Auckland: 252 p.
Edwards, E. n.d. Survey maps of the upper Fa'aroa Valley. On file with the Museé des Îles, Laboratoire d'Ethnologie Prehistorique, Tahiti.

Emory, K. P. 1933 Stone remains of the Society Islands: Bernice P. Bishop Museum Bulletin 116. 1943 Polynesian stone remains. In Coon, C. S. and Andrews, J. M. II, eds., Studies in Anthropology of Oceania and Asia. Papers of the Peabody Museum of American Archaeology and Ethnology 20: 9-21.

Emory, K. P. and Sinoto, Y. 1964 Eastern Polynesian burials at Maupiti. Journal of the Polynesian Society 73: 143-167.

(ms.) 1965 Preliminary report on the archaeological investigations in Polynesia. Mimeographed report for the National Science Foundation: On file with the Ber- 
nice P. Bishop Museum, Honolulu.

Garanger, J. 1964 Recherches archéologiques dans le district Tautira (Tahiti, Polynésie Française). Journal de la Société des Océanistes. 20: 5-21.

1980 Prospections archéologiques de l'ilot Fenuaino et des vallées Aiurea et Vaaiote à Tahiti. Journal de la Société des Océanistes. 36: 77-104.

Gerard, B. 1974 Contribution à l'etude des structures lithiques à caractére religieux aux îles de la Société: Ethnologie, archéologie. Memoire de stage de l'ORSTOM, Papeete, Tahiti.

Green, R. C. 1967 Survey and excavation at selected religious structures in the eastern portion of the 'Opunohu Valley. In Green, R. C., Green, K., Rappaport, R. A., Rappaport, A. and Davidson, J., eds., Archaeology of the Island of Mo'orea, French Polynesia. Anthropological Papers of the Museum of Natural History 51: 141-163.

Green, R. C. and Descantes, C. 1989 Site Records of the 'Opunohu Valley, Mo'orea. Auckland, University of Auckland, Green Foundation for Polynesian Research: $273 \mathrm{p}$.

Green, R. C. and Green, K. 1968 Religious structures (Marae) of the Windward Society Islands: The significance of certain historical records. The New Zealand Journal of History. 2: 68-89.

Green, R. C., Green, K., Rappaport, R. A., Rappaport, A. and Davidson, J. 1967 Archaeology of the Island of Mo'orea, French Polynesia. Anthropological Papers of the Museum of Natural History 51: 111-230.

Handy, E. S. C. 1930 History and culture in the Society Islands. Bernice P. Bishop Museum Bulletin 79: 110 p.

Kirch, P. V. 1986 Rethinking East Polynesian prehistory. Journal of the Polynesian Society 95: 9-40.

1994 The Wet and the Dry: Irrigation and Agricultural Intensification in Polynesia: Chicago, University of Chicago Press: $385 \mathrm{p}$.

Kirch, P. V. and Sahlins, M. 1992 Anahulu. The Anthropology of History in the Kingdom of Hawaii, 2 volumes. Chicago, The University Chicago Press: 444 p.
Lepofsky, D. (ms.) 1994 Prehistoric agricultural intensification in the Society Islands, French Polynesia. Ph.D. dissertation, University of California at Berkeley: $341 \mathrm{p}$.

Lepofsky, D., Harries, H. and Kellum, M. 1992 Early coconuts on Mo'orea Island, French Polynesia. Journal of the Polynesian Society 101: 299-308.

Lepofsky, D., Kirch, K. and Lertzman, K. 1996 Stratigraphic and paleobotanical evidence for prehistoric human-induced environmental disturbance on Mo'orea Island, French Polynesia. Pacific Science 50, in press.

Malarde, Y. 1936 Notes sur les valleés de Aiurua et Vaiote. Bulletin de la Société des Océanistes 5: 579_ 581.

Oliver, D. 1974 Ancient Tahitian Society, Vol. 1-3. Honolulu, University of Hawaii Press: 1419 p.

Parkes, A. and Flenley, J. 1990 The Hull University Moorea Expedition: Miscellaneous Series, no. 37. Department of Geography, University of Hull: 65 p.

Sahlins, M. 1958 Social Stratification in Polynesia: Seattle, University of Washington Press: 306 p.

Sinoto, Y. H. and Komori, E. (ms.) 1988 Settlement pattern survey of Mata'ire'a Hill, Maeva, Huahine Islands, French Polynesia: On file with the Bernice P. Bishop Museum, Honolulu: $82 \mathrm{p}$.

Spriggs, M. J. T. and Anderson, A. 1993 Late colonization of East Polynesia. Antiquity 67: 200-217.

Stuiver, M. and Kra, R. S., eds. 1986 Calibration Issue. Radiocarbon 28(2B): 806-1030.

Stuiver, M. and Polach, H. A. 1977 Discussion: Reporting of ${ }^{14} \mathrm{C}$ data. Radiocarbon 19(3): 355-363.

Verin, V. 1962 Prospection archaéologique préliminaire de Tetiaroa. Bulletin de la Societé des Etudes Océaniennes 139: 59-80.

Wallin, P. 1993 Ceremonial Stone Structures. The Archaeology and Ethnohistory of the Marae Complex in the Society Islands, French Polynesia: Aun, no. 18, Uppsala, Societas Archaeologica Upsaliensis: 178 p. 